Gut, 1985, 26, 32-37

\title{
Effect of Rowachol on biliary lipid secretion and serum lipids in normal volunteers
}

\author{
OTTMAR LEISS AND.KLAUS VON BERGMANN \\ From the Department of Medicine, University of Bonn, Bonn, Federal Republic of Germany
}

SUMmaRY The effect of Rowachol (200 mg tid), an essential oil preparation, on biliary lipid secretion and serum lipids was measured in six healthy male volunteers before and after four weeks of treatment. Biliary cholesterol and phospholipid secretion increased significantly from $113 \pm 36(\mathrm{SD}) \mu \mathrm{mol} / \mathrm{h}$ to $155 \pm 52 \mu \mathrm{mol} / \mathrm{h}(\mathrm{p}<0 \cdot 05)$ and from $409 \pm 145 \mu \mathrm{mol} / \mathrm{h}$ to $587 \pm 185 \mu \mathrm{mol} / \mathrm{h}$ $(\mathrm{p}<0.05)$, respectively. Bile acid secretion increased from $1519 \pm 662 \mu \mathrm{mol} / \mathrm{h}$ to $2287 \pm 1175$ $\mu \mathrm{mol} / \mathrm{h}(\mathrm{p}>0.05$ and $>0 \cdot 10)$. This marked increase in biliary lipid secretion was not followed by a change in molar composition of biliary lipids and lithogenicity of bile. Serum cholesterol and triglycerides declined from $4.9 \mathrm{mmol} / \mathrm{l}$ to $4.1 \mathrm{mmol} / \mathrm{l}(\mathrm{p}<0.05)$ and from $1.2 \mathrm{mmol} / \mathrm{l}$ to $0.9 \mathrm{mmol} / \mathrm{l}$ $(p<0.05)$ respectively. The ratio of high-density-lipoprotein cholesterol to total cholesterol increased from 0.22 to $0.31(\mathrm{p}<0.05)$. Although it has been shown previously that Rowachol could dissolve cholesterol gall stones the present results indicate that Rowachol alone has only weak litholytic properties, at least in normal volunteers, but might have several advantages when combined with chenodeoxycholic or ursodeoxycholic acid.

Chronic administration of either chenodeoxycholic acid or ursodeoxycholic acid has been shown to reduce lithogenicity of bile thereby promoting dissolution of cholesterol gall stones. ${ }^{1-3}$ Recently, another agent, Rowachol, has been shown to be effective in dissolving gall stone ${ }^{4} 5$ and biliary tract stones. ${ }^{6}$ This essential oil preparation containing the mono- and bicyclic monoterpenes menthol (32\% $\mathrm{w} / \mathrm{v})$, pinene $(17 \% \mathrm{w} / \mathrm{v})$, menthone $(6 \% \mathrm{w} / \mathrm{v})$, borneol $(5 \% \mathrm{w} / \mathrm{v})$, camphene $(5 \% \mathrm{w} / \mathrm{v})$ and cineole $(2 \% \mathrm{w} / \mathrm{v})$ in olive oil (ROWA-Wagner KG, 5060 Bergisch-Gladbach 1, FRG) has been used as a choleretic and therapeutic agent for biliary tract diseases in Europe for more than 25 years. $^{78}$ Whereas chenodeoxycholic acid and ursodeoxycholic acid reduce the lithogenecity of bile by decreasing biliary lipid output of cholesterol ${ }^{9-11}$ the mechanism by which Rowachol effect biliary lipid metabolism has not been elucidated. The purpose of the present study was to examine the effects of Rowachol on biliary lipid secretion and serum lipid concentration in normal volunteers.

Address for correspondence: Ottmar Leiss, MD, Medizinische Klinik, Universitaet Bonn, Sigmund-Freud-Strasse 25, 5300 Bonn-Venusberg. Federal Republic of Germany.

Received for publication 16 March 1984

\section{Methods}

EXPERIMENTAL DESIGN

Six healthy young male volunteers were studied as outpatients at the Metabolic Unit, Department of Medicine, University of Bonn. The study was conducted in accordance with the principles of the Helsinki declaration and informed consent was obtained from each subject. None of the subjects had evidence of gastrointestinal disease and routine liver function tests were normal. Age, body weight, and height are given in Table 1. During the study period each subject was on his usual diet and no changes in body weight occurred.

Biliary lipid secretion rates were measured before

Table 1 Age, body weight and height of the volunteers

\begin{tabular}{llll}
\hline Subject & Age $(\mathrm{yr})$ & Body weight $(\mathrm{kg})$ & Height $(\mathrm{cm})$ \\
\hline 1 & 23 & 84 & 184 \\
2 & 22 & 76 & 192 \\
3 & 25 & 77 & 190 \\
4 & 26 & 74 & 187 \\
5 & 25 & 70 & 176 \\
6 & 26 & 69 & 180 \\
\hline
\end{tabular}


and after four weeks of administration of Rowachol (200 mg tid). Blood was taken after an overnight fast before and after two and four weeks of administration of Rowachol. Serum was separated and stored at $-20^{\circ} \mathrm{C}$ until serum lipid analysis.

\section{EXPERIMENTAL PROCEDURE}

Biliary lipid secretion was measured by the intestinal perfusion technique described by Grundy and Metzger. ${ }^{12}$ The evening before the study the subjects were admitted to the Metabolic Ward where they swallowed a triple lumen tube. After an overnight fast the tube was positioned with two proximal outlets adjacent to the ampulla of Vater and a third outlet $10 \mathrm{~cm}$ distally just beyond the ligamentum of Treitz. A liquid formula diet (142 $\mathrm{cal} / \mathrm{kg} / \mathrm{h}$ ) containing $36 \%$ of calories as fat $(70 \%$ in the form of lard), $16 \%$ as protein and $48 \%$ as carbohydrates (Nutrodrip, Wander $\mathrm{GmbH}, 6522$ Osthofen, FRG) together with beta-sitosterol (22.5 $\mathrm{mg} / \mathrm{h}$ ) as a non-absorbable marker were infused constantly through the most proximal outlet. After allowing four hours for gall bladder contraction and stabilisation of hepatic bile secretion hourly samples were obtained for the following six hours from the second proximal and the distal outlet by continuous aspiration. During the regimen of Rowachol administration $400 \mathrm{mg}$ of this terpene mixture was given in the morning of the study before liquid formula infusion was started.

Storage of the proximal samples and separation of bile acids from cholesterol and phospholipids were performed according to the method used in the National Cooperative Gallstone Study. ${ }^{13}$ Ten millilitres of the distal samples were added to ethanol. In every proximal and distal sample, cholesterol and beta-sitosterol were measured by gas liquid chromatography as trimethylsilylethers ${ }^{14}$ using 5alpha-cholestane as internal standard. In every proximal sample bile acids were determined enzymatically ${ }^{15}{ }^{16}$ and phospholipids were measured by the method of Bartlett. ${ }^{17}$ Hourly outputs of cholesterol, bile acids and phospholipids were then calculated according to equations given by Grundy and Metzger ${ }^{12}$ along with correction factors for cholesterol content of the perfused formula. Biliary lipid composition was expressed as molar per cent for each lipid component according to Admirand and Small ${ }^{18}$ and per cent saturation was calculated by the criteria of Carey and Small ${ }^{19}$ assuming a total lipid content of hepatic bile of $5 \mathrm{~g} / \mathrm{dl}$.

Individual bile acids were determined in every proximal sample by gas liquid chromatography. The conjugated bile acids were deconjugated enzymatically (cholylglycin hydrolase; Sigma Chemicals Co, St. Louis, Mo. (20)) and solvolised. ${ }^{21}$
After methylation 22 and derivatisation to their trimethylsilylethers ${ }^{14}$ the individual bile acids were separated on a fused silica capillary column (SP 2100, $25 \mathrm{~m}$, ID $0 \cdot 20-0 \cdot 21 \mathrm{~mm}$, Hewlett Packard, Palo Alto, CA) using an automatic injection system (7671 A Automatic Sampler, Hewlett Packard).

\section{SERUM LIPIDS}

Total lipids, cholesterol, phospholipids and triglycerides were determined by the micromethod of Egge et al.$^{23}$ High-density-lipoprotein cholesterol was determined in the supernatant after precipitation of apolipoprotein-B containing lipoproteins with dextran sulphate/magnesium chloride ${ }^{24}$ using a micromethod described recently. ${ }^{25}$ Previous studies by one of us $^{25}$ have shown that high-density-lipoprotein-cholesterol determined by this micromethod was in good agreement with high-density-lipoprotein-cholesterol determined by ultracentrifugation according to Havel et $_{\text {al. }}{ }^{26}$

STATISTICAL ANALYSIS

The results are expressed as mean \pm SD. Results between control period and Rowachol administration were compared with the Wilcoxon's signed rank test.

\section{Results}

\section{EFFECT OF ROWACHOL ON BILIARY LIPID}

SECRETION

Biliary lipid outputs during control period and after administration of Rowachol are given in Table 2. Biliary cholesterol secretion averaged $113 \mu \mathrm{mol} / \mathrm{h}$ during control period and increased after administration of Rowachol by $37 \%$ to $155 \mu \mathrm{mol} / \mathrm{h}$ $(p<0.05)$. Biliary secretion of phospholipids averaged $409 \mu \mathrm{mol} / \mathrm{h}$ during control period and increased significantly by $36 \%$ to $587 \mu \mathrm{mol} / \mathrm{h}$ during Rowachol treatment $(\mathrm{p}<0.05)$. The average increase in bile acid secretion from $1519 \mu \mathrm{mol} / \mathrm{h}$ to $2287 \mu \mathrm{mol} / \mathrm{h}(51 \%)$ was not significant ( $>>0.05$ and $<0 \cdot 10)$. Administration of Rowachol had no effect on molar composition of cholesterol, bile acids, phospholipids or the lithogenic index (Table 3). Molar ratios of cholesterol to bile acids, cholesterol to phospholipids and phospholipids to bile acids during the control period averaged $0.09 \pm 0.03$, $0 \cdot 29 \pm 0.09$ and $0 \cdot 28 \pm 0 \cdot 07$, respectively. Administration of Rowachol did not alter these ratios $(0.08 \pm 0.03,0.27 \pm 0.05$ and $0.29 \pm 0.09$, respectively). No change in the molar composition of individual bile acids was observed during administration of Rowachol, except for lithocholic acid, the smallest fraction, which increased (Table 4). 
Table 2 Biliary lipid secretion rates in normal volunteers during control period and after four weeks of treatment with Rowachol (200 mg tid)

\begin{tabular}{|c|c|c|c|c|c|c|}
\hline \multirow[b]{2}{*}{ Subject } & \multicolumn{2}{|c|}{ Cholesterol $(\mu \mathrm{mol} / \mathrm{h} \pm S D)$} & \multicolumn{2}{|c|}{ Phospholipids ( $\mu \mathrm{mol} / \mathrm{h} \pm S D$ ) } & \multicolumn{2}{|c|}{ Bile acids $(\mu \mathrm{mol} / \mathrm{h} \pm S D)$} \\
\hline & $\mathrm{CO}$ & ROW & $\mathrm{CO}$ & $R O W$ & $\mathrm{CO}$ & $R O W$ \\
\hline $\begin{array}{l}1 \\
2 \\
3 \\
4 \\
5 \\
6\end{array}$ & $\begin{array}{c}151 \pm 16 \\
90 \pm 14 \\
122 \pm 17 \\
57 \pm 8 \\
151 \pm 5 \\
109 \pm 23\end{array}$ & $\begin{array}{l}133 \pm 43 \\
141 \pm 22 \\
155 \pm 18 \\
119 \pm 43 \\
255 \pm 41 \\
125 \pm 22\end{array}$ & $\begin{array}{l}579 \pm 92 \\
253 \pm 65 \\
590 \pm 146 \\
334 \pm 149 \\
405 \pm 34 \\
295 \pm 59\end{array}$ & $\begin{array}{l}582 \pm 269 \\
673 \pm 173 \\
568 \pm 117 \\
473 \pm 166 \\
884 \pm 191 \\
339 \pm 65\end{array}$ & $\begin{array}{r}1484 \pm 252 \\
913 \pm 177 \\
2689 \pm 755 \\
1415 \pm 240 \\
1725 \pm 179 \\
888 \pm 214\end{array}$ & $\begin{array}{l}1845 \pm 894 \\
2752 \pm 548 \\
2570 \pm 720 \\
1090 \pm 354 \\
4245 \pm 596 \\
1219 \pm 265\end{array}$ \\
\hline$\overline{\mathbf{x}} \pm \mathrm{SD}$ & $113 \pm 36$ & $155 \pm 51 \dagger$ & $409 \pm 145$ & $587 \pm 185 \dagger$ & $1519 \pm 662$ & $2287 \pm 1175 \ddagger$ \\
\hline
\end{tabular}

Abbreviations: $\mathrm{CO}=$ Control period; ROW $=$ Rowachol period.

* Values for each subject represent the average for 6 determinations during the steady state period of formula infusion.

$\dagger$ Significantly different from $\mathrm{CO}(\mathrm{p}<0 \cdot 05)$.

$\ddagger \mathrm{p}$ between $0 \cdot 05$ and $0 \cdot 10$.

EFFECT OF ROWACHOL ON SERUM LIPIDS

Mean total lipids, cholesterol, triglycerides and phospholipids before, after two and four weeks of treatment with Rowachol are presented in Table 5. A significant reduction of triglyceride concentration in serum was observed after two and four weeks. Phospholipids and total lipids showed a significant decrease after four weeks. High-density-lipoproteincholesterol increased slightly (14\%) after four weeks, and with the parallel small but not significant decrease in total cholesterol the ratio of highdensity-lipoprotein-cholesterol to total cholesterol increased significantly $(\mathrm{p}<0.05)$.

\section{Discussion}

\section{EFFECTS OF ROWACHOL ON BILIARY LIPID} SECRETION

The results of this study in normal volunteers show that administration of Rowachol (200 mg tid) for four weeks increases biliary outputs of bile acids, phospholipids, and cholesterol to almost the same rate extending previous studies in animals ${ }^{27}$ and preliminary results in patients with indwelling $T$ tube after cholecystectomy. ${ }^{28}$ The obtained secretion rates of biliary lipids are in the same range as in other groups of normal volunteers published previously $^{29}$ as well as studied recently in our department. (In 20 healthy volunteers the hourly secretion rates of cholesterol, phospholipids, bile acids and the LI of hepatic bile averaged $120 \pm 19$, $420 \pm 140,1776 \pm 277 \mu \mathrm{mol} / \mathrm{h}$ and $0.96 \pm 0.26$, respectively). Whether the present results obtained in normal volunteers might be extrapolated to patients with cholesterol gall stones has to be elucidated. How Rowachol promote this parallel increase in output of all biliary lipids remains unclear. Other drugs for treatment of cholesterol gall stone disease or hyperlipidemia do not induce such remarkable effects on biliary lipid secretion.

Table 3 Biliary lipid composition and lithogenic index of stimulated hepatic bile in normal volunteers during control period and after 4 weeks of treatment with Rowachol (200 mg tid)

\begin{tabular}{|c|c|c|c|c|c|c|c|c|}
\hline \multirow[b]{2}{*}{ Subject } & \multicolumn{2}{|c|}{$\begin{array}{l}\text { Cholesterol } \\
\left(\text { molar \%) (mean } \pm S D^{*}\right)\end{array}$} & \multicolumn{2}{|c|}{$\begin{array}{l}\text { Phospholipids } \\
\left.\text { (molar \%) (mean } \pm S D^{*}\right)\end{array}$} & \multicolumn{2}{|c|}{$\begin{array}{l}\text { Bile acids } \\
\left(\text { molar \%) (mean } \pm S D^{*}\right)\end{array}$} & \multicolumn{2}{|c|}{$\begin{array}{l}\text { Lithogenic Index } \\
(C S)\left(\text { mean } \pm S D^{*}\right)\end{array}$} \\
\hline & $C O$ & ROW & $C O$ & ROW & $\mathrm{CO}$ & ROW & $C O$ & $R O W$ \\
\hline $\begin{array}{l}1 \\
2 \\
3 \\
4 \\
5 \\
6\end{array}$ & $\begin{array}{l}6.9 \pm 0.7 \\
7 \cdot 2 \pm 0.7 \\
3 \cdot 7 \pm 0.6 \\
3 \cdot 2 \pm 0.2 \\
6 \cdot 6 \pm 0.4 \\
8 \cdot 5 \pm 0.1\end{array}$ & $\begin{array}{l}5 \cdot 6 \pm 1 \cdot 3 \\
4 \cdot 0 \pm 0 \cdot 3 \\
4.9 \pm 0 \cdot 8 \\
7 \cdot 1 \pm 1 \cdot 3 \\
4 \cdot 7 \pm 0 \cdot 5 \\
7 \cdot 5 \pm 0.7\end{array}$ & $\begin{array}{l}26 \cdot 2 \pm 1 \cdot 5 \\
20 \cdot 3 \pm 5 \cdot 2 \\
17 \cdot 5 \pm 1 \cdot 7 \\
18 \cdot 1 \pm 5 \cdot 1 \\
17 \cdot 8 \pm 0 \cdot 5 \\
23 \cdot 0 \pm 2 \cdot 3\end{array}$ & $\begin{array}{l}24 \cdot 0 \pm 6 \cdot 5 \\
18 \cdot 7 \pm 2 \cdot 1 \\
17 \cdot 4 \pm 1 \cdot 1 \\
28 \cdot 2 \pm 4 \cdot 7 \\
16 \cdot 3 \pm 1 \cdot 8 \\
20 \cdot 3 \pm 1 \cdot 4\end{array}$ & $\begin{array}{l}66 \cdot 9 \pm 2 \cdot 0 \\
72 \cdot 5 \pm 5 \cdot 6 \\
78 \cdot 8 \pm 2 \cdot 0 \\
78 \cdot 7 \pm 5 \cdot 2 \\
75 \cdot 6 \pm 0 \cdot 8 \\
68 \cdot 5 \pm 2 \cdot 8\end{array}$ & $\begin{array}{l}70 \cdot 4 \pm 6 \cdot 8 \\
77 \cdot 3 \pm 2 \cdot 1 \\
77 \cdot 7 \pm 1 \cdot 9 \\
64 \cdot 7 \pm 5 \cdot 9 \\
79 \cdot 0 \pm 1 \cdot 9 \\
72 \cdot 2 \pm 2 \cdot 0\end{array}$ & $\begin{array}{l}0.93 \pm 0.11 \\
1 \cdot 18 \pm 0.08 \\
0.70 \pm 0.11 \\
0.59 \pm 0.12 \\
1.20 \pm 0.07 \\
1.29 \pm 0.09\end{array}$ & $\begin{array}{l}0.84 \pm 0.19 \\
0.71 \pm 0.05 \\
0.91 \pm 0.14 \\
0.93 \pm 0.20 \\
0.92 \pm 0.07 \\
1.23 \pm 0.10\end{array}$ \\
\hline$\overline{\mathbf{x}} \pm \mathrm{SD}$ & $6 \cdot 0 \pm 2 \cdot 1$ & $5 \cdot 6 \pm 1 \cdot 4$ & $20 \cdot 5 \pm 3 \cdot 5$ & $20 \cdot 8 \pm 4 \cdot 5$ & $73 \cdot 5 \pm 5 \cdot 1$ & $73 \cdot 6 \pm 5 \cdot 5$ & $0.98 \pm 0.29$ & $0.92 \pm 0.17$ \\
\hline
\end{tabular}

Abbreviations: $\mathrm{CO}=$ Control period; $\mathrm{ROW}=$ Rowachol period; $\mathrm{CS}=$ Lithogenic Index calculated according to Carey and Small ${ }^{19}$ assuming a total lipid content of hepatic bile of $5 \mathrm{~g} / \mathrm{dl}$.

* Values for each subject represent the average for 6 determinations during the steady state period of formula infusion. 
Table 4 Mean molar per cent of individual bile acids in bile in normal volunteers during control period and after four weeks of treatment with Rowachol (200 mg tid)

\begin{tabular}{|c|c|c|c|c|c|c|c|c|c|c|}
\hline \multirow[b]{2}{*}{ Subject } & \multicolumn{2}{|c|}{ LICA (molar \%*) } & \multicolumn{2}{|c|}{$D C A\left(\right.$ molar $\left.\%^{*}\right)$} & \multicolumn{2}{|c|}{$C D C A\left(\operatorname{molar} \%^{*}\right)$} & \multicolumn{2}{|c|}{$C A\left(\operatorname{molar} \% \%^{*}\right)$} & \multicolumn{2}{|c|}{ UDCA (molar \%*) } \\
\hline & $C O$ & ROW & $C O$ & ROW & $C O$ & ROW & $C O$ & $R O W$ & $C O$ & $R O W$ \\
\hline $\begin{array}{l}1 \\
2 \\
3 \\
4 \\
5 \\
6\end{array}$ & $\begin{array}{l}0.29 \\
0.52 \\
0.12 \\
0.98 \\
0.85 \\
1.26\end{array}$ & $\begin{array}{l}1.09 \\
0.72 \\
0.98 \\
1.03 \\
1.86 \\
1.17\end{array}$ & $\begin{array}{l}19 \cdot 95 \\
24 \cdot 03 \\
20 \cdot 80 \\
25 \cdot 79 \\
15 \cdot 20 \\
17 \cdot 32\end{array}$ & $\begin{array}{l}31 \cdot 58 \\
24 \cdot 16 \\
19 \cdot 45 \\
23 \cdot 01 \\
19 \cdot 42 \\
12 \cdot 29\end{array}$ & $\begin{array}{l}39 \cdot 24 \\
41 \cdot 15 \\
43 \cdot 37 \\
53 \cdot 12 \\
43 \cdot 92 \\
49 \cdot 62\end{array}$ & $\begin{array}{l}38 \cdot 82 \\
47 \cdot 33 \\
43 \cdot 48 \\
46 \cdot 58 \\
44 \cdot 55 \\
49 \cdot 33\end{array}$ & $\begin{array}{l}37 \cdot 64 \\
30 \cdot 03 \\
30 \cdot 64 \\
15 \cdot 32 \\
39 \cdot 07 \\
30 \cdot 11\end{array}$ & $\begin{array}{l}29 \cdot 48 \\
24 \cdot 07 \\
32 \cdot 03 \\
26 \cdot 14 \\
33 \cdot 15 \\
36 \cdot 10\end{array}$ & $\begin{array}{l}2.87 \\
4.26 \\
5.08 \\
4.80 \\
0.96 \\
1.69\end{array}$ & $\begin{array}{l}1 \cdot 04 \\
3.72 \\
4 \cdot 06 \\
3.24 \\
1 \cdot 02 \\
1 \cdot 11\end{array}$ \\
\hline $\begin{array}{l}\text { Mean } \\
\pm \mathrm{SD}\end{array}$ & $\begin{array}{l}0.67 \\
0.43\end{array}$ & $\begin{array}{l}1 \cdot 14 \dagger \\
0.38\end{array}$ & $\begin{array}{r}20.51 \\
3.98\end{array}$ & $\begin{array}{r}21 \cdot 65 \\
6 \cdot 39\end{array}$ & $\begin{array}{r}45 \cdot 07 \\
5 \cdot 27\end{array}$ & $\begin{array}{r}45.02 \\
3.67\end{array}$ & $\begin{array}{r}30 \cdot 16 \\
4 \cdot 50\end{array}$ & $\begin{array}{r}30.47 \\
8.43\end{array}$ & $\begin{array}{l}3 \cdot 28 \\
1 \cdot 71\end{array}$ & $\begin{array}{l}2 \cdot 37 \\
1.46\end{array}$ \\
\hline
\end{tabular}

Abbreviations: LICA = lithocholic acid; $D C A=$ deoxycholic acid; $\mathrm{CDCA}=$ chenodeoxycholic acid; $\mathrm{CA}=$ cholic acid; UDCA = ursodeoxycholic acid; $\mathrm{CO}=$ Control period; $\mathrm{ROW}=$ Rowachol period.

* Values for each subject represent the average for 6 determinations during the steady state period of formula infusion.

$\dagger$ Significantly different from $\mathrm{CO}(\mathrm{p}<0 \cdot 05)$.

The observed increase of biliary lipid output had no consistent effect on lithogenicity of hepatic bile. Molar ratios of cholesterol to bile acids, cholesterol to phospholipids and phospholipids to bile acids were not changed after Rowachol administration indicating that this terpene mixture did not alter the coupling of cholesterol or phospholipids to bile acids. As shown in Table 3, however, in four of the volunteers with a lithogenic index greater than 0.9 treatment with Rowachol slightly decreased the lithogenic index. These results are comparable with those of acute studies by Doran et al. ${ }^{30}$ With the same dose regimen these investigators found a significant decrease in cholesterol saturation of gall bladder bile obtained by needle aspiration in patients at the time of abdominal surgery.

\section{EFFECTS OF ROWACHOL ADMINISTRATION ON} SERUM LIPIDS

The beneficial effects of Rowachol on serum lipids

Table 5 Mean serum lipids during control period and after 2 weeks and 4 weeks of administration of Rowachol (200 mg tid)

\begin{tabular}{|c|c|c|c|}
\hline & $\begin{array}{l}C O \\
(\text { mean } \pm S D)\end{array}$ & $\begin{array}{l}2 \text { weeks } \\
\text { (mean } \pm S D)\end{array}$ & $\begin{array}{l}4 \text { weeks } \\
\text { (mean } \pm S D\end{array}$ \\
\hline Total lipids (g/l) & $6.53 \pm 0.91$ & $6 \cdot 40 \pm 0 \cdot 69$ & $5 \cdot 22 \pm 1 \cdot 14^{*}$ \\
\hline Triglycerides $(\mathrm{mmol} / \mathrm{l})$ & $1.22 \pm 0.29$ & $0.95 \pm 0.22^{*}$ & $0.87 \pm 0.29 *$ \\
\hline Phospholipids (mmol/1) & $2 \cdot 89 \pm 0.92$ & $3.09 \pm 0.68$ & $2 \cdot 09 \pm 0.62^{*}$ \\
\hline Total cholesterol $(\mathrm{mmol} / \mathrm{l})$ & $4.91 \pm 0.38$ & $4.89 \pm 0.63$ & $4.07 \pm 0.64$ \\
\hline HDL-cholesterol (mmol/1) & $1 \cdot 09 \pm 0 \cdot 14$ & $1.38 \pm 0.32$ & $1 \cdot 25 \pm 0.23$ \\
\hline$\frac{\text { HDL-cholesterol }}{\text { Total cholesterol }}$ & $0 \cdot 22 \pm 0 \cdot 04$ & $0 \cdot 28 \pm 0 \cdot 06^{*}$ & $0.31 \pm 0.05^{*}$ \\
\hline
\end{tabular}

Abbreviations: $\mathrm{CO}=$ Control period ROW $=$ Rowachol period.

* Significantly different from $\mathrm{CO}(\mathrm{p}<0.05)$. support previous studies in patients with cholestasis $^{28}$ and hyperlipoproteinaemia. ${ }^{31-33}$ The significant increase in the absolute values of highdensity-lipoprotein-cholesterol during treatment with this terpene preparation observed by Bell et $a l^{34}$ and Hordinsky and Hordinsky ${ }^{33}$ could not be confirmed in the present study, probably because normolipidemic volunteers were studied during shorter treatment periods. When expressed as relative values, however, (ratio of high-densitylipoprotein-cholesterol to total cholesterol) the change from 0.22 to 0.31 was statistically significant $(p<0.05)$. The beneficial effect of this terpene preparation on serum lipids might be of advantage for treatment of hyperlipidemic patients with increased risk factors for gall stone formation as common lipid lowering drugs like clofibrate, ${ }^{35} 36$ bezafibrate, ${ }^{37}$ and probably nicotinic acid ${ }^{36} 38$ increase lithogenicity of bile.

\section{MECHANISM OF CHOLESTEROL GALL STONE}

DISSOLUTION BY ROWACHOL

The mechanism whereby Rowachol induces cholesterol gall stone dissolution is not clear. In the present study the lithogenic index in normal volunteers was not influenced consistently by Rowachol, in contrast with known effects of chenodeoxycholic acid and ursodeoxycholic acid. Thus, other effects after Rowachol administration seems also to be important for gall stone dissolution. In addition to the relative concentration of bile acids, phospholipids and cholesterol total lipid content of bile is another important determinant of cholesterol solubility. ${ }^{19}$ In the present study Rowachol increased total lipid output and total lipid concentration of duodenal content $(0.67 \mathrm{~g} / 1$ versus $0.87 \mathrm{~g} / \mathrm{l}$; $\mathrm{p}<0.05)$. This observation is in line with results of 
Bell $e t a l^{39}$ who show that Rowachol (100 mg tid) given to gall stone patients three months before cholecystectomy increased biliary lipid concentration significantly. Thus, the increase in biliary lipid concentration produced by Rowachol might contribute to the litholytic properties of this mixture of plant monoterpenes. Furthermore, several of the terpenes - for example, menthol, menthone and pinene - are excellent cholesterol solvents in vitro. The structurally related terpene, d-limonene, has recently been used as an agent for dissolving common duct scenes. ${ }^{40}$ Therefore, physicochemical properties of some of the individual components of Rowachol may also contribute to the cholelitholytic effects. Although, administration of Rowachol alone might dissolve gall stone in some some patients, ${ }^{45}{ }^{41}$ a combination with chenodeoxycholic acid or ursodeoxycholic acid might be of advantage for several reasons. First, the dissolution rates of gall stone may be accelerated, as already shown by Ellis et al. ${ }^{41} 42$ Second, the dose of chenodeoxycholic acid or ursodeoxycholic acid might be lowered, decreasing the cost of medical gall stone dissolution. And third, the lipid lowering effect of this essential oil preparation may prevent the increase of LDL-cholesterol observed by the National Cooperative Gallstone Study during chenodeoxycholic acid therapy. ${ }^{43}$ A combination of Rowachol with ursodeoxycholic acid might be even more effective in reducing lithogenicity of bile. Preliminary results from our department in a randomised study indicate that low dose ursodeoxycholic acid ( $250 \mathrm{mg} /$ day) combined with Rowachol decreased the lithogenic index of super-saturated gall bladder bile in patients with gall stones and/or hyperlipoproteinaemia more (from 1.88 to 1.02 ; $\mathrm{p}<0.01, \mathrm{n}=6$ ) than low dose chenodeoxycholic acid (250 mg/day) plus Rowachol (from 1.32 to 1.33 ; $\mathrm{n}=6)$ or ursodeoxycholic acid alone $(1000 \mathrm{mg} / \mathrm{day}$; from 1.00 to $0.77 ; p<0.05$, hepatic bile, $n=6$ ).

The work was supported by grant Le $385 / 1$ of the Deutsche Forschungsgemeinschaft, Bonn, FRG. The authors thank Mrs P Pitters and G Westphal and $\mathrm{Mr} \mathrm{S}$ Weiner for excellent technical assistance.

\section{References}

1 Danzinger RG, Hofmann AF, Schoenfield LJ, Thistle JL. Dissolution of cholesterol gallstones by chenodeoxycholic acid. $N$ Engl J Med 1972; 286: 1-8.

2 Bell CD, Whitney B, Dowling RH. Gallstone dissolution in man using chenodeoxycholic acid. Lancet 1972; 2: 1213-6.

3 Makino J, Shinizaki K, Nakagawa K, Yoshino K. Dissolution of cholesterol gallstones by ursodeoxy- cholic acid. Jpn J Gastroenterol 1975; 72: 690-702.

4 Hordinsky BZ. Terpenes in the treatment of gallstones. Minn Med 1971; 54: 649-52.

5 Bell GD, Doran J. Gall stone dissolution in man using an essential oil preparation. Br Med J 1979; 279: 24.

6 Ellis WR, Bell GD. Treatment of biliary duct stones with a terpene preparation. $\mathrm{Br}$ Med $J$ 1981; 282: 611 .

7 Sarreither W. Rowachol-Cholex, ein terpenhaltiges Praeparat zur Behandlung der Cholelithiasis. Med Monatsschr 1955; 9: 97-9.

8 Weithaler, K. Zur Therapie der Gallenwegserkrankungen. Med Klinik 1959; 54: 1645-9.

9 Adler RD, Bennion LJ, Duane WC, Grundy SM. Effects of low dose chenodeoxycholic acid feeding on biliary lipid metabolism. Gastroenterology 1975; 68: 326-34.

10 LaRusso NF, Hoffman NE, Hofmann AF, Northfield TC, Thiestle JL. Effect of primary bile acid ingestion on bile acid metabolism and biliary lipid secretion in gallstone patients. Gastroenterology 1975; 69: 1301-14.

11 Von Bergmann $\mathrm{K}$, Epple-Gutsfeld $\mathbf{M}$, Leiss $\mathrm{O}$. Differences in the effects of chenodeoxycholic and ursodeoxycholic acid on biliary lipid secretion and bile acid synthesis in patients with gallstones. Gastroenterology 1984; 87: 136-43.

12 Grundy SM, Metzger AL. A physiological method for estimation of hepatic secretion of biliary lipids in man. Gastroenterology 1972; 62: 1200-17.

13 Hofmann AF, Grundy SM, Lachin JM, et al. Pretreatment biliary lipid composition in white patients with radiolucent gallstones in the National Cooperative Gallstone Study. Gastroenterology 1982; 83: 738-52.

14 Grundy SM, Ahrens EH Jr, Miettinen TA. Quantitative isolation and gas-liquid chromatographic analysis of total fecal bile acids. J Lipid Res 1965; 6: 397-410.

15 Talalay P. Enzymatic analysis of steroid hormones. Methods Biochem Anal 1960; 8: 114-43.

16 Paumgartner G, Horak W, Probst P, Grabner G. Effect of phenobarbital on bile flow and bile salt excretion in the rat. Naunyn-Schmiedeberg's Arch Pharmakol 1971; 270: 98-102.

17 Bartlett GR. Phosphorous assay in column chromatography. J Biol Chem 1959; 234: 466-8.

18 Admirand WH, Small DM. The physicochemical basis of cholesterol gallstone formation in man. J Clin Invest 1968; 47: 1043-52.

19 Carey M, Small DM. The physical chemistry of cholesterol solubility in bile. Relationship to gallstone formation and dissolution in man. J Clin Invest 1978; 61: 998-1026.

20 Nair PP, Gordon M, Reback J. The enzymatic cleavage of the carbon-nitrogen bound in 3-alpha,7-alpha,12alpha-trihydroxy-5-beta-cholan-25-oylglycine. J Biol Chem 1967; 242: 7-11.

21 van Berge Henegouwen GP, Allan RN, Hofmann AF, Yu PYS. A facile hydrolysis-solvolysis procedure for conjugated bile acid sulfates. J Lipid Res 1977; 18: 118-22.

22 Schlenk H, Gellermann JL. Esterification of fatty acids with diazomethane on a small scale. Anal Chem 1960; 32: $1412-4$. 
23 Egge $\mathbf{H}$, Murawski, U, Mueller J, Zilliken F. Mikrolipidanalysen aus Serum mit dem Eppendorfsystem 3000. Z Klin Chem Klin Biochem 1970; 8: 488-91.

24 Burstein M, Scholnick HR. Lipoprotein-polyanionmetal interactions. Adv Lipid Res 1973; 11: 67-108.

25 Leiss O, Murawski U, Egge H. Mikrobestimmung von Lipoproteinlipiden im Serum. J Clin Chem Clin Biochem 1979; 17: 619-25.

26 Havel RJ, Eder HA, Bragdon JH. The distribution and chemical composition of ultracentrifugally separated lipoproteins in human serum. J Clin Invest 1955; 34: 1345-53.

27 Moersdorf K, Wolf G. Untersuchungen zur Wirkungspotenz einiger Choleretika. Dtsch Med J 1966; 10: 303-6.

28 Kopp H. Zur klinischen Wirksamkeit von Rowachol. Arch Arzneit 1976; 1: 21-38.

29 von Bergmann K, Mok HY, Hardison WGM, Grundy SM. Cholesterol and bile acid metabolism in moderately advanced, stable cirrhosis of the liver. Gastroenterology 1979; 77: 1183-92.

30 Doran J, Keighley MRB, Bell GD. Rowachol - a possible treatment for cholesterol gallstones. Gut 1979; 20: 312-7.

31 Clotten R. Wirksamkeit des Terpengemisches Rowachol bei gestoerter Leberfunktion. Muench Med Wochenschr 1972; 114: 256-61.

32 Beiglboeck W. Ueber die Wirkung aetherischer Oele auf die sekretorische Leberfunktion und das Serumcholesterin. Wiener Med Wochenschr 1960; 110: 11-6.

33 Hordinsky BZ, Hordinsky W. Rowachol - seine Verwendung bei Hyperlipaemie. Arch Arzneif 1979; 1: 45-51.

34 Bell GD, Bradshaw JP, Burgess A, et al. Elevation of serum high density lipoprotein cholesterol by Rowachol, a proprietary mixture of six pure mono- terpenes. Atherosclerosis 1980; 36: 47-54.

35 Pertsemlidis D, Panveliwalla D, Ahrens EH Jr. Effects of clofibrate and of an estrogen-progestin combination on fasting biliary lipids and cholic acid kinetics in man. Gastroenterology 197?; 66: 565-73.

36 Angelin B, Einarsson K, Leijd B. Biliary lipid composition during treatment with different hypolipidaemic drugs. Eur J Clin Invest 1979; 9: 185-90.

37 von Bergmann $K$, Leiss $O$. Effect of short-term treatment with bezafibrate and fenofibrate on biliary lipid metabolism in patients with hyperlipoproteinaemia. Eur J Clin Invest 1984; 14: 150-4.

38 Grundy SM, Mok HYI, Zech L, Berman M. Influence of nicotinic acid on metabolism of cholesterol and triglycerides in man. $J$ Lipid Res 1981; 22: 24-36.

3.9 Bell GD, Clegg RJ, Ellis WR, Middleton B, Sommerville K, White DA. How does Rowachol, a mixture of plant monoterpenes, enhance the litholytic potential of low and medium dose chenodeoxycholic acid? Br J Clin Pharmacol 1982; 13: 278P-9P.

40 Igimi $H$, Hisatsugu $T$, Nishimura $M$. The use of d-limonen preparation as a dissolving agent of gallstones. Dig Dis 1976; 21: 926-39.

41 Ellis WR, Somerville KW, Rose DH, Axon ATR, Bell GD. Terpene treatment for gallstones: five year experience with Rowachol 1977-82. [Abstract] Gut 1982; 23: A882-3.

42 Ellis WR, Bell GD, Middleton B, White DA. Adjunct to bile-acid treatment for gall-stone dissolution: lowdose chenodeoxycholic acid combined with a terpene preparation. $\mathrm{Br}$ Med J 1981; 282: 611-2.

43 Albers JJ, Grundy SM, Cleary PA, Small DM, Lachin JM, Schoenfield LJ, and the National Cooperative Gallstone Study Group: National Cooperative Gallstone Study. The effect of chenodeoxycholic acid on lipoproteins and apolipoproteins. Gastroenterology 1982; 82: 638-46. 